\title{
Vertical distribution of division rates in coastal dinoflagellate Dinophysis spp. populations: implications for modelling
}

\author{
L. Velo-Suárez ${ }^{1, *}$, B. Reguera ${ }^{1}$, E. Garcés ${ }^{2}$, T. Wyatt ${ }^{3}$ \\ ${ }^{1}$ Instituto Español de Oceanografía, Centro Oceanográfico de Vigo, Aptdo. 1552, 36200 Vigo, Spain \\ ${ }^{2}$ Institut de Ciències del Mar (CSIC), Passeig Marítim de la Barceloneta 37-49, 08003 Barcelona, Spain \\ ${ }^{3}$ Instituto de Investigaciones Marinas (CSIC), Eduardo Cabello 6, Bouzas, 36208 Vigo, Spain
}

\begin{abstract}
This study explores vertical heterogeneities of in situ division rates $(\mu)$ of 3 species of Dinophysis and discusses its implications in modelling the population dynamics of these species. Based on a post-mitotic index approach, estimates of $\mu$ from vertical net-haul (integrated) samples $\left(\mu_{\text {int }}\right)$ were compared with those from a single depth (oceanographic bottle samples) $\left(\mu_{z}\right)$ at the cell maximum during 2 daily cell cycle studies in the Galician Rías Baixas (NW Spain). Additionally, vertical profiles of $\mu_{z}$ were obtained during a field survey in Ría de Vigo. A 2-fold difference was observed between estimates of $\mu_{z}$ from the cell maxima and $\mu_{\text {int }}$ from integrated samples under stratified conditions. Differences were much larger when the minimum estimates of $\mu$ values from different depths $\left(\mu_{\min }\right)$ were compared within single vertical profiles. An exponential growth model was applied to simulate the dynamics of a $D$. acuminata population during a daily cycle in June 1994. Results show that actively dividing cells of a target species may be restricted to narrow layers of the water column. Estimates of $\mu$ at different relevant depths during cell cycle studies may be key to determining whether if increased numbers of a target species are due to in situ growth or to the balance of imports and exports.
\end{abstract}

KEY WORDS: Dinophysis spp. C Cell cycle · In situ division rate · Mitotic index · Cell maximum · Modelling approach

\section{INTRODUCTION}

The development of Dinophysis spp. populations that produce lipophilic shellfish toxins (LSTs) — okadaic acid (OA), dinophysistoxins (DTXs) and pectenotoxins (PTXs) - represents a major hazard for the Northeast Atlantic shellfish industry (Reguera \& Pizarro 2008). Chronic occurrences of Dinophysis spp. result in shellfish with LSTs above levels permitted in the EU (Anonymous 1991, 2002) leading to prolonged bans on harvesting in affected areas. To improve prediction of LST outbreaks (including their duration and decline) it is essential to identify the different scenarios - with regard to in situ growth, behaviour (vertical migration, aggregation), physically induced accumula- tion (advection, downwelling, convergence areas) and physical-biological interactions - that may promote numerical increase of Dinophysis spp. populations.

The specific division rate, $\mu$, is an important intrinsic parameter in the growth equation that needs to be determined. This parameter estimates the potential for intrinsic division without the interference of losses due to grazing, mortality and physical dispersion (Carpenter \& Chang 1988). Even more important for modelling purposes is to estimate $\mu_{\max }$, i.e. the maximum potential division rate of the species under optimal conditions when resources are not limiting. In the present study we consider $\mu_{\max }$ as the maximum division rate estimated for a target species in a given scenario. It is to be expected that $\mu_{\max }$ of a species, at a given time 
and place, will be observed at its optimum depth in the water column, i.e. the depth where the combination of environmental conditions (resources and physicalbiological interactions) are the most suitable for that species' growth and survival.

Dinophysis spp. and other toxin-producing algae (TPA) species that transmit toxins through the food web - even at moderate to low concentrations $\left(10^{2}\right.$ to

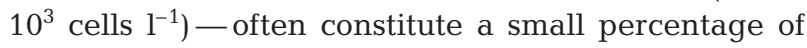
the total phytoplankton community. Bulk measurements using chemical indicators such as chlorophyll $a$ concentration and primary production are unsuitable for growth studies of these rare TPA species since they reflect the physiology not of the target organisms but of the whole plankton community. Estimates of $\mu$ from in situ cell cycle studies are time-consuming, but provide realistic information on the division capabilities of the species in question (Reguera et al. 2003).

Estimates of $\mu$ in field populations of Dinophysis spp. have been obtained either from incubations, on deck or in diffusion chambers (Garcés et al. 1997) or from direct in situ high frequency sampling with a mitotic index approach (Table 1). Dinophysis spp. often exhibit sharp heterogeneities in their vertical distribution (reviewed in Reguera \& Pizarro 2008, Velo-Suárez et al. 2008). To minimize sampling uncertainties derived from low cell concentrations, vertical migration or patchiness (which would result in samples with inadequate numbers of target cells), in situ division rate studies of Dinophysis spp. have been carried out mainly using vertical net-hauls to obtain integrated samples from the whole water column. In this way, integrated values of $\mu\left(\mu_{\text {int }}\right)$ rather than values of $\mu$ at specific depths $\left(\mu_{z}\right)$ are obtained; however estimates of $\mu_{\max }$, i.e. the maximum value of $\mu$ in a given scenario, are unobtainable.

Potential growth is often greater than observed net growth, and differences between the two are attributed to cell losses (Garcés \& Masó 2001). Net changes in population density result from the balance between gains (growth and physical accumulation) and losses (grazing, mortality and physical dispersion). Knowledge of the variations of these parameters is thus fundamental to understanding the processes leading to bloom formation and maintenance. The contribution of division and mortality rates to Dinophysis spp. population dynamics in the Rías Baixas can be analyzed with the use of a simplified biological model. Although these models are generally unable to represent all the variability of an ecosystem, they can provide the necessary framework for exploring different aspects of harmful algae outbreaks (Franks 1997).

In the present study, we compare values of $\mu$ estimated from integrated water-column samples (hereafter referred to as 'integrated samples') $\left(\mu_{\text {int }}\right)$ with values based on samples collected at specific depths $\left(\mu_{z}\right)$, especially those collected at the depth where the maximum concentration of Dinophysis spp., $P_{\max }$ was detected $\left(\mu_{P_{\max }}\right)$. The importance of vertical heterogeneities in division rates of populations and their implications for population dynamic models are discussed.

Table 1. Dinophysis spp. In situ estimated division rates (mitotic index approach; $\mathrm{d}^{-1}$ ) of several species of Dinophysis. For D. acuminata, 1 st value: polynomial curve fit; 2 nd value: periodic curve fit

\begin{tabular}{|c|c|c|c|c|}
\hline Species & Location & Date & $\mu\left(\mathrm{d}^{-1}\right)$ & Source \\
\hline \multirow[t]{7}{*}{ D. acuminata } & Long Island, NY, USA & Jul 1997 & 0.54 & Chang \& Carpenter (1991) \\
\hline & & & 0.67 & \\
\hline & Galician Rías, Spain & Jun 1994 & 0.47 & Reguera et al. (2003) \\
\hline & & Oct 1994 & 0.26 & \\
\hline & & Jun 1997 & 0.09 & \\
\hline & & Jun 2005 & 0.56 & S. González-Gil et al. (unpubl.) \\
\hline & Gullmar Fjord, Sweden & Oct 1995 & 0.75 & Gisselson et al. (1999) \\
\hline \multirow[t]{3}{*}{ D. acuta } & Galician Rías, Spain & Oct 1994 & 0.65 & Reguera et al. (2003) \\
\hline & & Oct 1997 & 0.33 & \\
\hline & & Nov 2005 & 0.03 & Pizarro et al. (2008) \\
\hline \multirow[t]{2}{*}{ D. caudata } & Galician Rías, Spain & Oct 1994 & 0.24 & Reguera et al. (2003) \\
\hline & & Oct 1997 & 0.25 & \\
\hline D. fortii & Santa Monica Bay, CA, USA & Jun 1975 & 0.5 & Weiler \& Chisholm (1976) \\
\hline D. norvegica & Baltic Sea & Jul-Aug 1998 & $0.1-0.4$ & Gisselson et al. (2002) \\
\hline D. tripos & Galician Rías, Spain & Oct 1994 & 0.5 & Reguera et al. (2003) \\
\hline \multirow[t]{4}{*}{ D. sacculus } & Ebro Delta, Spain & May 1994 & 0.42 & Garcés et al. (1997) \\
\hline & & Jun 1994 & 0.28 & \\
\hline & & Jun 1994 & 0.38 & \\
\hline & & Oct 1994 & 0.2 & \\
\hline
\end{tabular}




\section{MATERIALS AND METHODS}

The present study is based on samples from 2 diel cycle studies conducted on board the RV 'J. M. Navaz' in the Galician Rías in late spring and early autumn 1994 at the time of numerical increases of Dinophysis spp. and shellfish harvesting closures. These samples were used to estimate $\mu$ on integrated samples $\left(\mu_{\text {int }}\right)$ and at Dinophysis spp. cell maxima $\left(\mu_{P_{\max }}\right)$ and to evaluate differences between them. For the late-spring period, an exponential growth model was applied to simulate the $42^{\circ} 15^{\prime}$ population dynamics of Dinophysis spp in the Galician Rías. This model was used to determine the influence of both $\mu_{\text {int }}$ and $\mu_{P_{\max }}$ on Dinophysis population dynamics.

In addition, differences between $\mu_{z}$ at diverse specific depths, including the depths of cell maxima, were studied with a fine-resolution vertical profile of Dinophysis spp.

Diel cycles. Dinophysis spp. sampling and cell counts: Phytoplankton samples were collected by vertical $20 \mu \mathrm{m}$ mesh net hauls in the upper 20 to $25 \mathrm{~m}$ to obtain integrated samples of the whole water column. To eliminate debris and large zooplankton, samples were passed through a $150 \mu \mathrm{m}$ mesh and fixed with buffered formaldehyde. Simultaneously, CTD (SBE 25 SEALOGGER) casts were carried out to obtain vertical profiles of temperature, salinity and in vivo fluorescence. Oceanographic bottles were used to collect samples at specific depths. Aliquots for phytoplankton counting were immediately fixed with Lugol's iodine acidic solution (Lovegrove 1960).

Daily values of offshore Ekman transport $\left(\mathrm{m}^{3} \mathrm{~s}^{-1}\right.$ $\mathrm{km}^{-1}$ ) were calculated from geostrophic wind data off Cape Finisterre, a representative site for the Rías Baixas, according to Bakun (1973).

The spring cruise (1 to 2 June 1994) was carried out over $22 \mathrm{~h}$ at fixed Stn P2 (27 m deep, $\left.42^{\circ} 21^{\prime} \mathrm{N}, 8^{\circ} 47^{\prime} \mathrm{W}\right)$ in Ría de Pontevedra (Fig. 1). Vertical net hauls and inverted 51 bottle samples were collected at 5, 10, 15 and $20 \mathrm{~m}$ every hour from $17: 00$ to $20: 00 \mathrm{~h}$ and $00: 00$ to 14:00 $\mathrm{h}$ and every $2 \mathrm{~h}$ from 20:00 to 00:00 h. The autumn cruise (27 to 28 October 1994) was carried out during $36 \mathrm{~h}$ at fixed Stn V1 (20 m deep, $42^{\circ} 15^{\prime} \mathrm{N}, 8^{\circ} 50^{\prime} \mathrm{W}$ ) in Ría de Vigo (Fig. 1). Vertical hauls and bottle samples from the cell maxima were collected every $2 \mathrm{~h}$ from 13:00 to 17:00 h, hourly from 17:00 to 04:00 h and every half hour from 04:00 to 12:00 $\mathrm{h}$ (the time window when cellular division processes take place in Dinophysis spp.; Reguera et al. 2003). Depths at which to sample the cell maxima were chosen after reading the CTD profiles and performing quick on-board microscopic observation of concentrated bottle samples from depths where density discontinuities and/or in vivo fluorescence were observed. The $5 \mathrm{l}$ bottle samples were concentrated through a collector with a $20 \mu \mathrm{m}$ end to a final volume of about $8^{\circ} 45^{\prime}$

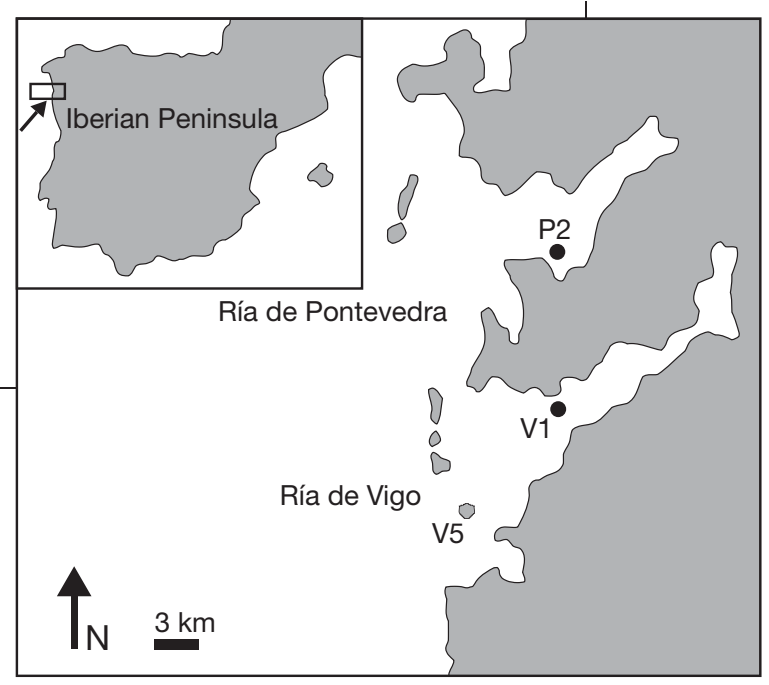

Fig. 1. Rías Vigo and Pontevedra, Iberian Peninsula, showing locations of sampling stations P2, V1 and V5

$50 \mathrm{ml}$, which was measured to calculate the conversion factor for the cell counts. Dinophysis spp. from all Lugol's-fixed samples cells were counted by the Utermöhl (1931) method under a Zeiss (AXIOVERT 135) inverted microscope, after sedimentation from $25 \mathrm{ml}$ columns. Vertical distributions of physical parameters and cell densities were plotted with the Microcal ORIGIN and Golden Software SURFER contour software.

Estimates of division rates: In situ division rates were estimated from the frequency of dividing (paired) and recently divided (incomplete development of the left sulcal list) cells, which were recognized by their distinct morphology as described in Reguera et al. (2003), following the model of Carpenter \& Chang (1988):

$$
\mu=\frac{1}{n\left(T_{\mathrm{c}}+T_{\mathrm{r}}\right)} \sum_{\mathrm{i}=1}^{\mathrm{n}}\left(t_{\mathrm{s}}\right)_{\mathrm{i}} \ln \left[1+f_{\mathrm{c}}\left(t_{\mathrm{i}}\right)+f_{\mathrm{r}}\left(t_{\mathrm{i}}\right)\right]
$$

where $\mu$ is the daily average specific division rate, $f_{\mathrm{c}}\left(t_{\mathrm{i}}\right)$ is the frequency of cells in the cytokinetic (or paired cells) phase (c) and $f_{\mathrm{r}}\left(t_{\mathrm{i}}\right)$ is the half frequency of cells in the recently divided (r) phase in the $i$ th sample. $T_{\mathrm{c}}$ and $T_{\mathrm{r}}$ are the duration of the $\mathrm{c}$ and $\mathrm{r}$ phases, considered as terminal events (sensu Carpenter \& Chang 1988) in the present study; $\mathrm{n}$ is the number of samples taken in a $24 \mathrm{~h}$ cycle; and $t_{\mathrm{s}}$ is the sampling interval in hours. In the case of Dinophysis caudata, opening pairs (cytokinetic pairs where the dividing cells are not in the same plane) were used instead of paired cells to calculate the frequency of dividing cells. Recently divided cells were counted when incomplete development of the left sulcal list occurred, whether they were single cells or pairs. The duration of the selected terminal events, $T_{\mathrm{c}}+T_{\mathrm{r}}$, was estimated as the interval of time necessary for a cohort of cells to pass from one phase to the next; 
in this case, the time interval between time $t_{0}$, when the frequency of cells undergoing cytokinesis $\left(f_{\mathrm{c}}\right)$ is maximum, and time $t_{1}$, when the fraction of recently divided cells $f_{\mathrm{r}}$ is maximum:

$$
\frac{1}{2}\left(T_{\mathrm{c}}+T_{\mathrm{r}}\right)=\left(t_{0}-t_{1}\right)
$$

where $T_{\mathrm{C}}, T_{\mathrm{r}}, t_{1}$ and $t_{0}$ are calculated after fitting a 5 th degree Gaussian function to the frequency data.

An average $\mu\left(\mu_{\text {int }}\right)$ of the whole water column was estimated from the integrated samples obtained by vertical net hauls, and $\mu_{P \max }$ from the concentrated bottle samples collected at the depth of Dinophysis spp. cell maxima $\left(P_{\max }\right)$.

Modelling approach. An exponential growth model was applied to simulate the population dynamics of Dinophysis acuminata on 1 to 2 June 1994.

$$
P_{t}=P_{0} \mathrm{e}^{(\mu+I-E-g) t}
$$

where $P_{t}$ and $P_{0}$ are the population densities at times $t$ and 0 , respectively; $\mu$ is the specific division rate; $g$ is the cell loss rate by grazing; and $I$ and $E$ are the import and export rates, respectively. This equation was applied to both integrated, $P_{\text {int, }}$ and cell maximum, $P_{\text {max }}$ counts. Import and export rates include biological vertical migration, physical advection and eddy diffusion. Import and export rates as well as loss rates due to grazing were unknown, and were estimated as a single value (net growth rate, $h$ ) calculated every hour before $(\mu=0)$, during $\left(\mu=\mu_{\text {inti }} \mu_{P \max }\right)$ and after division $(\mu=0)$. Values of $\mu_{\text {int }}$ and $\mu_{P \max }$ were known from the daily cycle results, which showed that a phased-cell division took place from 7:00 to 10:00 h.

Vertical profiles of $\mu_{z}$. Dinophysis spp. sampling and cell counts: Samples were collected on board R/V 'Mytilus' on 21 August 2003 off Ría de Vigo at Stn V5 (100 m deep, 42 07.43' N, 8 58.55' W) (Fig. 1). Vertical profiles of temperature, salinity and in vivo fluorescence were obtained from a CTD (Seabird SBE 911) attached to a rosette sampler (Gral Oceanics 1015) equipped with twelve 101 oceanographic bottles used to collect water samples from the pycnocline region and from the water layers above and below it. Two kinds of subsamples were taken from each discrete depth (oceanographic bottles) sample: (1) $100 \mathrm{ml}$ was fixed with Lugol's solution, which was used for cell counts; and (2) the rest of the sample was poured into a bucket and gently concentrated by pouring the bucket content through a PVC cylindrical collector with a $20 \mu \mathrm{m}$ mesh that was kept with its lower half submerged in seawater to avoid cell damage. This concentrate, used to estimate frequency of cells undergoing division, was backwashed and fixed with neutral formaldehyde. Dinophysis spp. cells were counted as described above ('Diel cycles').
Estimates of division rates: The maximum frequency approach (McDuff \& Chisholm 1982) was used to estimate $\mu_{\text {min }}$ at each depth $\left(\mu_{z}\right)$ in single vertical profiles:

$$
\mu_{\min }=\ln \left(1+f_{\max }\right)
$$

where $f_{\max }$ is the frequency of dividing cells at each depth. This approach assumes that all cells which divide in a given day can be recognized as undergoing or just having completed mitosis in one sample. The sample should be collected during the appropriate time-window within which peak division is observed. In the case of Dinophysis acuta and D. caudata, the appropriate time has been confirmed, in several cycle studies, to be 2 to $3 \mathrm{~h}$ following sunrise (Reguera et al. 2003, Pizarro et al. 2008).

\section{RESULTS}

\section{Hydrographic conditions and phytoplankton distribution in diel cycle experiments}

In early June, there was a marked thermohaline stratification and a prominent subsurface chlorophyll maximum (SCM) at 10.5 to $11.5 \mathrm{~m}$ (Fig. 2A,B). Downwelling-favourable winds on 31 May (Fig. 3A) promoted a downward movement of the $23.5 \sigma_{t}$ isopycnal and a displacement of the pycnocline and the SCM below $10 \mathrm{~m}$ depth at the beginning of the survey (Fig. 3B). Wind direction changed to upwellingfavourable on 1 June and reversed again at the end of the survey (Fig. 3A). In response to the northerly winds, the $23.5 \sigma_{\mathrm{t}}$ isopycnal rose to $0-5 \mathrm{~m}$ from $00: 00 \mathrm{~h}$ on 2 June to the end of the cruise (Fig. 3B). The highest concentrations of Dinophysis acuminata were found at $10 \mathrm{~m}$ at 2:00 $\mathrm{h}\left(4379\right.$ cells $\left.\mathrm{l}^{-1}\right)$ and at $5 \mathrm{~m}$ from 08:00 to 10:00 h $\left(6058\right.$ cells l$\left.^{-1}\right)$ on 2 June (Fig. 3B). The average concentration of $D$. acuminata throughout the cycle was 1280 cells $\mathrm{l}^{-1}$ in integrated samples (0 to $20 \mathrm{~m}$ ).

The October survey took place under typical rainy autumn conditions after the end of the upwelling season. Sampling was carried out during the decline of the autumn maximum of Dinophysis acuminata and preceding a very moderate peak of $D$. acuta and the annual maxima of D. caudata and D. tripos. A homogeneous vertical distribution of temperature $\left(16^{\circ} \mathrm{C}\right)$ and salinity (34 to $34.4 \mathrm{psu}$ ) was observed below $6 \mathrm{~m}$ at Stn V1 (Fig. 2C). Heavy rainfall led to the formation of a strong halocline in the top 4 to $6 \mathrm{~m}$, especially in the first half of the cell cycle sampling (Fig. 2C). There was not a marked SCM (Fig. 2D), temperature in the top $10 \mathrm{~m}$ ranged from 15 to $16^{\circ} \mathrm{C}$ and salinity from 32 to $34.5 \mathrm{psu}$. In the integrated samples, the average concentration of $D$. caudata (0 to $15 \mathrm{~m}$ ) was very low $\left(160\right.$ cells $\left.1^{-1}\right)$. 

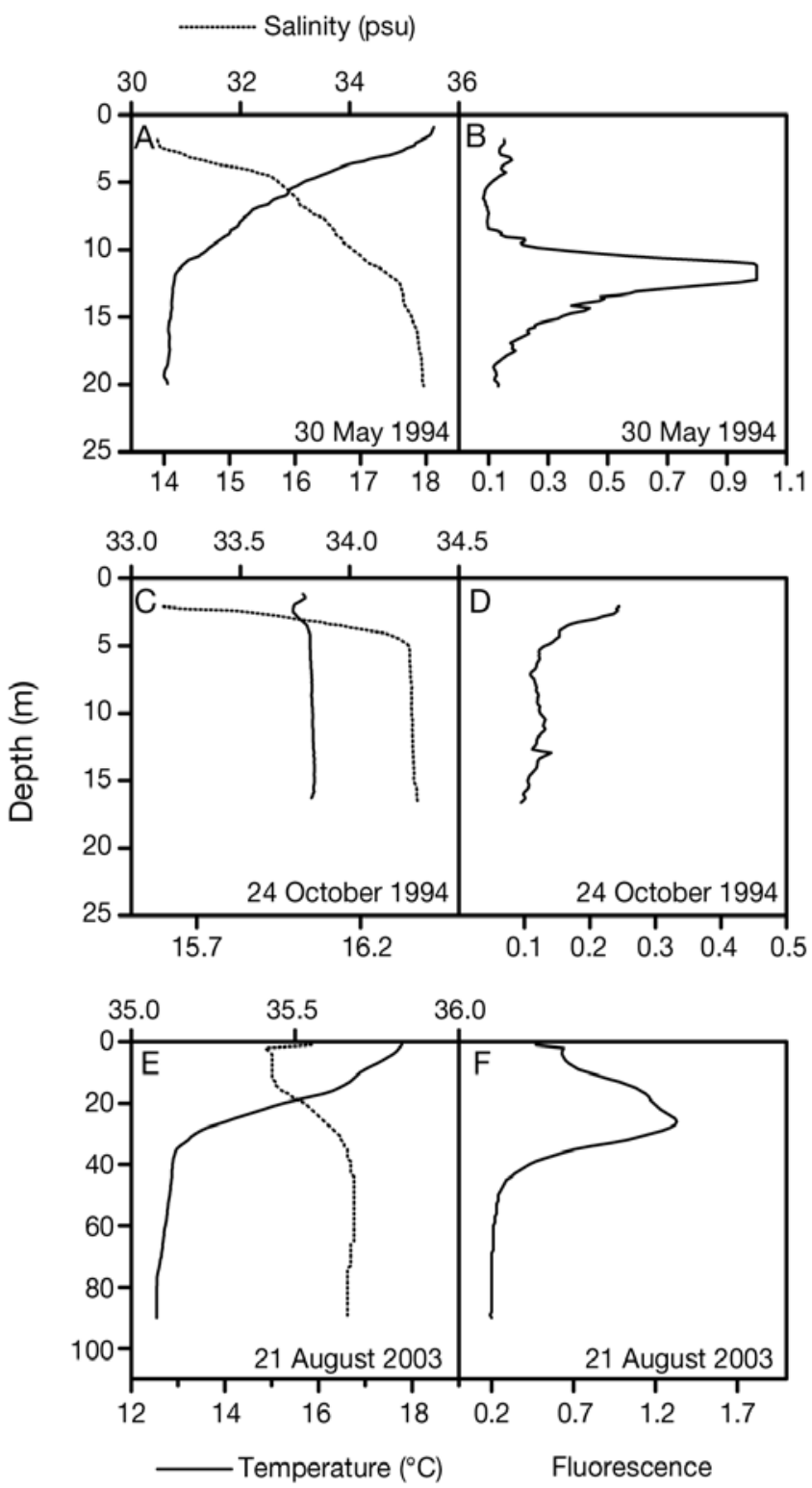

Fig. 2. Vertical profiles of $(A, C, E)$ temperature and salinity, and $(\mathrm{B}, \mathrm{D}, \mathrm{F})$ in vivo fluorescence (arbitrary units). (A,B) Stn P2, 30 May 1994 (prior to the 1-2 June cruise). (C,D) Stn V1, 24 October 1994 (prior to the 27-28 October cruise). (E,F) Stn V5, 21 August 2003

\section{Phase-fraction curves and estimates of $\mu$ in integrated and $\boldsymbol{P}_{\max }$ samples in diel cycles}

June cycle

Fig. 4 shows the distribution of frequencies of dividing $\left(f_{\mathrm{c}}\right)$ and recently divided $\left(f_{\mathrm{r}}\right)$ cells, as well as the estimated minimum growth rates $\left(\mu_{\min }\right)$ and the mean daily specific $\mu$ for Dinophysis acuminata during the June cycle, both in integrated samples and at the depth of $P_{\max }$. D. acuminata showed a clear-cut phased cell division in both situations. The highest values of $f_{\mathrm{C}}$ (0.11) and $f_{\mathrm{r}}(0.17)$ in integrated samples were lower than at $P_{\max }\left(f_{\mathrm{c}}=0.16, f_{\mathrm{r}}=0.21\right)$. The maximum $f_{\mathrm{c}}$ at $P_{\max }$ occurred at 05:00 h (just before sunrise) at $5 \mathrm{~m}$, and at 6:00 h (after sunrise) in the integrated samples. Whilst cytokinesis and sulcal-list regeneration lasted from 05:00 to 10:00 $\mathrm{h}$ in integrated samples, these terminal events occurred from 05:00 to 08:00 h at $P_{\max }$. Therefore, cell division was more synchronized at $P_{\max }$.

Estimates of $\mu$ and $\mu_{\min }$, according to Eqs. (1) \& (4), were $0.46 \pm 0.05 \mathrm{~d}^{-1}$ and $0.25 \mathrm{~d}^{-1}$, respectively, in integrated samples, and $0.40 \pm 0.04 \mathrm{~d}^{-1}$ and $0.21 \mathrm{~d}^{-1}$ at $P_{\max }$ (Table 2).

\section{October cycle}

Fig. 5 shows the distribution of $f_{\mathrm{c}}$ and $f_{\mathrm{r}}$, as well as $\mu_{\text {min }}$ and the mean daily specific $\mu$, for Dinophysis caudata during the October sampling for both the integrated and the $P_{\max }$ (4 to $6 \mathrm{~m}$ ) samples. The highest values of $f_{\mathrm{C}}(0.47)$ and $f_{\mathrm{r}}(0.45)$ at $P_{\max }$ were considerably higher than in integrated samples $\left(f_{\mathrm{C}}=0.10, f_{r}=0.21\right)$. While both $f_{\mathrm{c}}$ and $f_{\mathrm{r}}$ were similar and close to 0.50 at $P_{\text {max }}$ maximum values of $f_{\mathrm{r}}$ (up to 0.20 ) were higher than those of $f_{\mathrm{c}}(0.10)$ in integrated samples. The $f_{\mathrm{c}}$ and $f_{\mathrm{r}}$ maxima were observed at 08:30 and 11:00 h, respectively, at $P_{\max }$ and at 09:00 and 10:30 $\mathrm{h}$ in the integrated water column samples. Left sulcal-list regeneration (maximum $f_{\mathrm{r}}$ ) at $P_{\max }$ was observed from 08:00 to 14:00 $\mathrm{h}$ and from 08:00 to 16:00 $\mathrm{h}$ in the integrated samples. Thus, $f_{\mathrm{C}}$ lasted longer in the integrated population than at $P_{\max }$. Increasing values of $f_{\mathrm{c}}$ were observed at the end of the cycle (06:00 to 08:00 h) at $P_{\max }$. Both estimates of $\mu$ and $\mu_{\min }$ at $P_{\max }$ were double those of the integrated samples.

\section{Modelling results}

Results from the application of the exponential growth model to the June 1994 cycle are shown in Fig. 6. Hourly estimates of the net growth rate $(h)$ of the Dinophysis acuminata population, both at the cell maximum, $P_{\max }$ and in integrated samples, followed the same pattern. They showed an increase of $D$. acuminata in the dark phase, around midnight (20:00 to 01:00 h), with a peak at 01:00 h that was more pronounced at $P_{\max }(10 \mathrm{~m})$. From 02:00 to 06:00 h, $h$ fluctuated around zero, and losses were again more pronounced at $P_{\max }$. From 07:00 to 08:00 h, D. acuminata concentrations increased at both $P_{\max }$ and in the integrated water column, followed by an increase of loss factors, even during division, from 08:00 to 10:00 h. Estimates of $h$ exceeded estimates of growth calcu- 
A

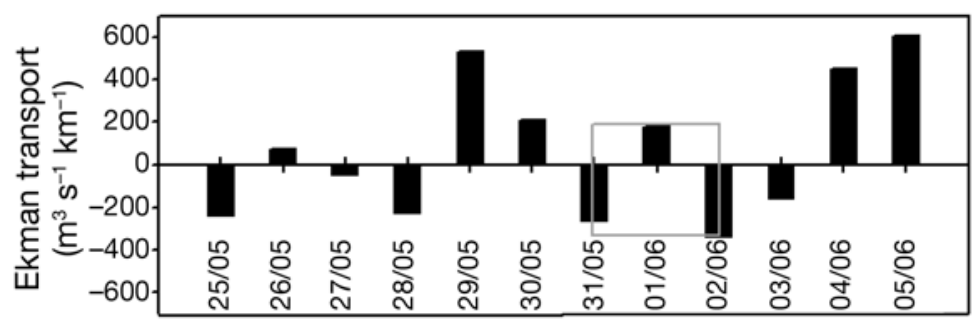

Date $(\mathrm{dd} / \mathrm{mm})$

B

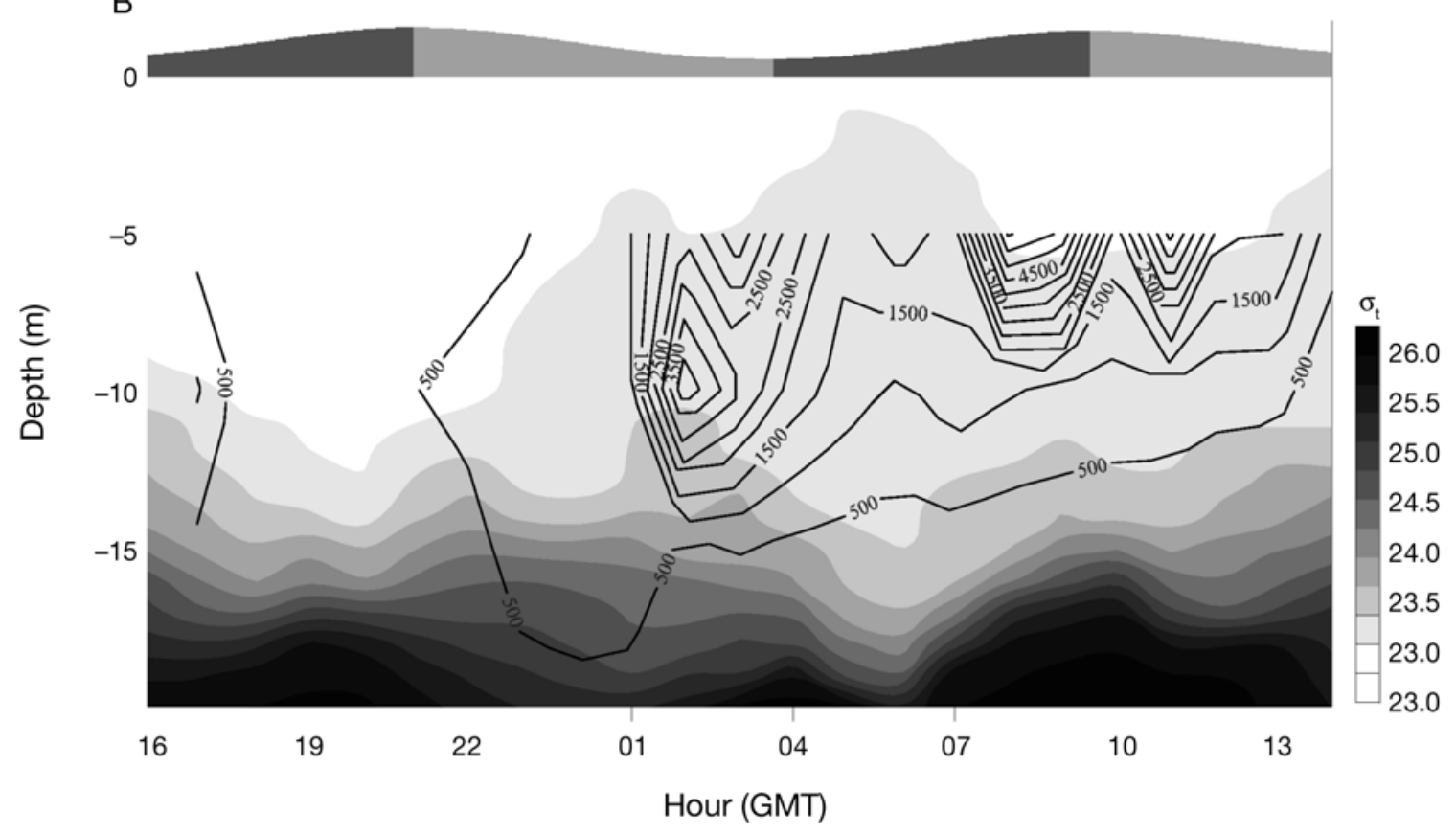

Fig. 3. (A) Ekman transport from 25 May to 3 June 1994 (values from 31 May to 2 June are outlined with a grey box). (B) Vertical distribution of seawater density $\left(\sigma_{t}\right)$ (gray background shadow) and Dinophysis acuminata (cell $\mathrm{l}^{21}$ ) (contour lines) obtained from bottle samples at 5, 10, 15 and $20 \mathrm{~m}$ at Stn P2 in Ría de Pontevedra from 16:00 (1 June 1994) to 14:00 h (2 June 1994). Tidal state is indicated on the horizontal bar above the panel

lated from division; therefore, the Dinophysis spp. population at that moment (07:00 h) not only increased by cellular division but also due to import factors. These gains (07:00 h) and losses (08:00 to 10:00 h) were also higher at $P_{\max }$. Even at 09:00 $\mathrm{h}$, when division occurred, $h$ reached a minimum.

\section{Vertical profiles of $\mu_{z}$ values}

Hydrographic conditions during the August 2003 sampling on the shelf corresponded to those typical in summer during mild upwelling pulses. Vertical profiles of temperature and salinity (Fig. 2E) showed marked discontinuities at around $20 \mathrm{~m}$ and the distribution of in vivo fluorescence (Fig. 2F) showed a broad chlorophyll a peak around the same depth. Dinophysis caudata and $D$. acuta maxima $\left(P_{\max }\right)$ were located in the $20 \mathrm{~m}$ discontinuity layer (Fig. 6). Although both Dinophysis spp. were found at this density discontinuity, D. caudata was more concentrated in the lower and D. acuta in the upper part of the pycnocline.

Table 2. Dinophysis acuminata and D. caudata. Division rates $\left(\mathrm{d}^{-1}\right)$ during diel cycles. Data for $\mu$ are mean \pm SD

\begin{tabular}{|lccccc|}
\hline Species & $\begin{array}{c}\text { Temperature } \\
\left({ }^{\circ} \mathrm{C}\right)\end{array}$ & $\begin{array}{c}\text { Salinity } \\
(\%)\end{array}$ & $\begin{array}{c}T_{\mathrm{c}}+T_{\mathrm{r}} \\
(\mathrm{h})\end{array}$ & $\begin{array}{c}\mu \\
\left(\mathrm{d}^{-1}\right)\end{array}$ & $\begin{array}{c}\mu_{\min } \\
\left(\mathrm{d}^{-1}\right)\end{array}$ \\
\hline $\begin{array}{l}\text { D. acuminata } \\
\text { Integrated }\end{array}$ & $17-18$ & $32-33$ & 2.1 & $0.46 \pm 0.05$ & 0.25 \\
Maximum & & & 1.6 & $0.40 \pm 0.04$ & 0.21 \\
$\begin{array}{l}\text { D. caudata } \\
\text { Integrated }\end{array}$ & $15-16$ & $30-35$ & 3.8 & $0.22 \pm 0.02$ & 0.18 \\
Maximum & & & 6.1 & $0.45 \pm 0.05$ & 0.38 \\
\hline
\end{tabular}




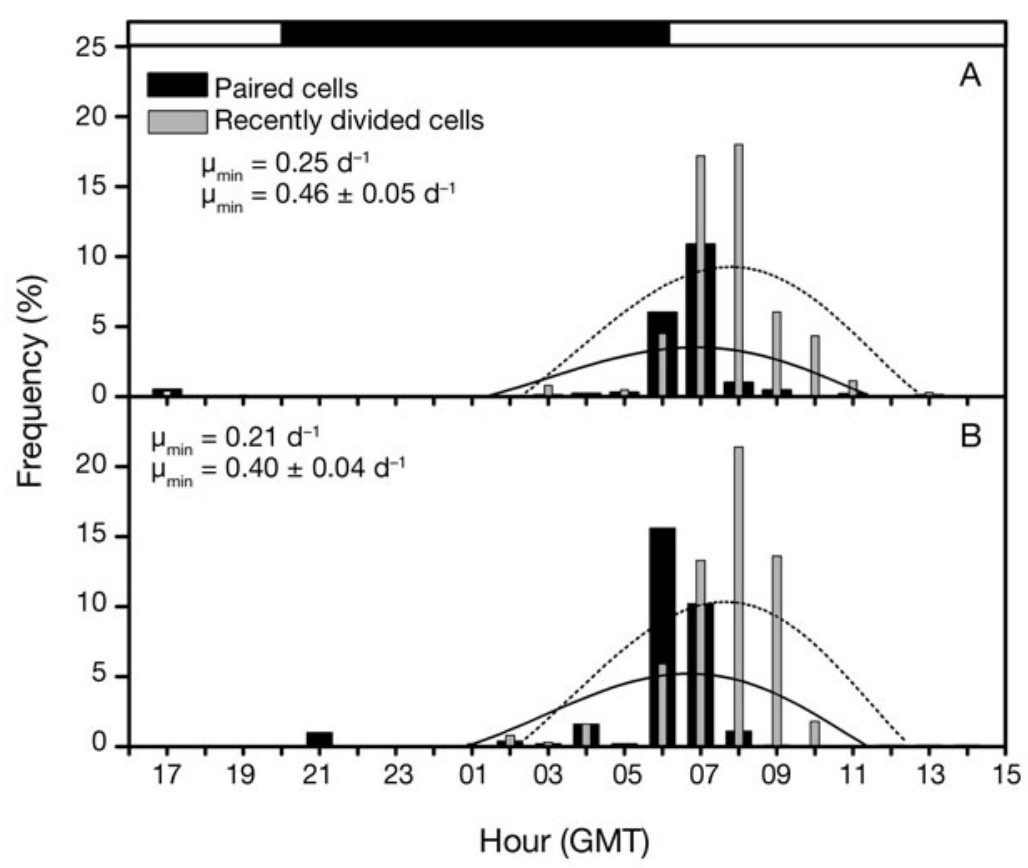

Fig. 4. Dinophysis acuminata. Diel distribution of frequencies of paired (dividing) and recently divided cells of $D$. acuminata, fitted to a 5th degree polynomial curve, 1 to 2 June 1994. (A) Integrated samples, (B) at cell maximum. Solid and dashed lines: estimated fitted curve for the frequency of paired cells, and recently divided cells, respectively. Black shading in bar at top: period between sunset and sunrise

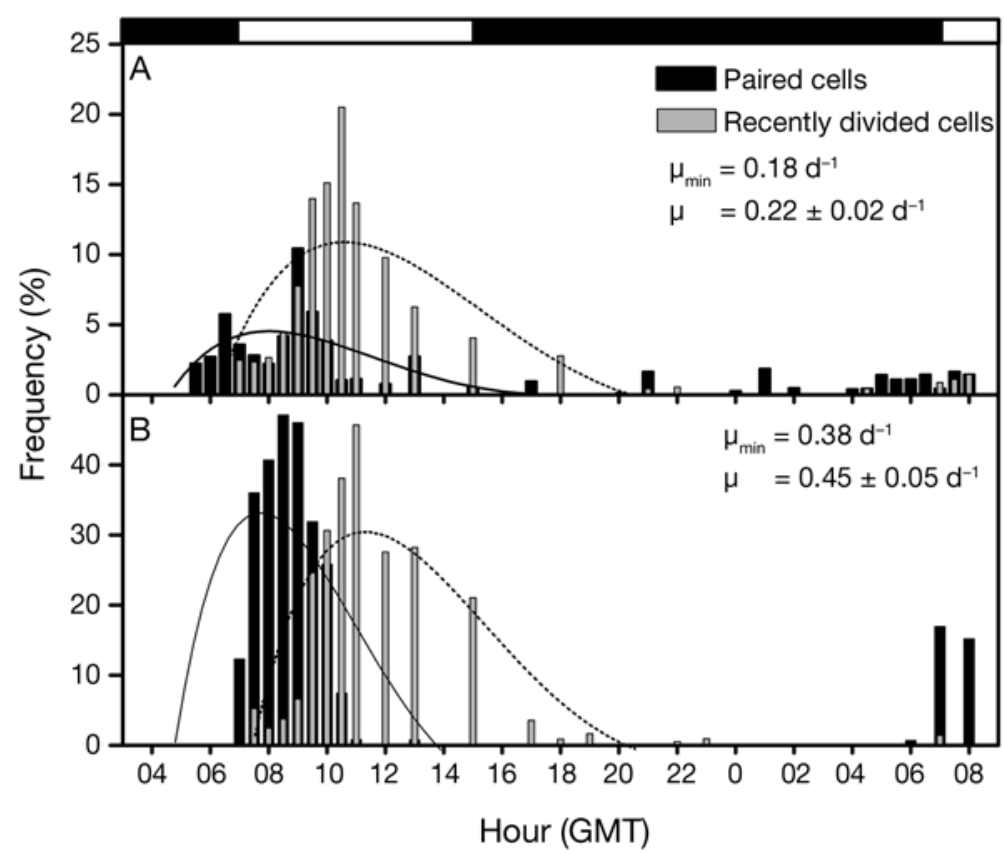

Fig. 5. Dinophysis caudata. Diel distribution of frequencies of paired (dividing) and recently divided cells of $D$. caudata, fitted to a 5th degree polynomial curve, 27 to 28 October 1994. (A) Integrated samples, (B) at cell maximum (pycnocline). Solid and dashed lines: estimated fitted curve for the frequency of paired cells, and recently divided cells, respectively. Black shading in bar at top: period between sunset and sunrise
Vertical profiles of $\mu_{\text {min }}$ at each sampling depth for Dinophysis acuta and D. caudata are shown in Fig. 7. The highest values of $\mu_{z}$ were found overlapping the $P_{\max }$ of both $D$. acuta and $D$. caudata, i.e. their maximum $\mu_{z}$ and $\mu_{P \max }$ values were equal.

\section{DISCUSSION}

Species-specific measurements of in situ division rates in dinoflagellate populations are scarce (Stolte \& Garcés 2006). This is especially true in the case of low biomass populations of TPA species, which often occur embedded in phytoplankton assemblages dominated by diatoms. In these cases, bulk measurement of chlorophyll, primary production and other biochemical markers do not reflect the physiology of the target species. The post-mitotic index method applied in the present study has been shown to provide a simple and reliable way to estimate in situ division rates of Dinophysis spp., even when these dinoflagellates are present at low to moderate concentrations $\left(10^{2}\right.$ to $10^{3}$ cells $\left.\mathrm{l}^{-1}\right)$ (Reguera et al. 2003).

Dinophysis spp. responsible for diarrhoeic shellfish poisoning (DSP) outbreaks have been labelled slow-growth species (Smayda \& Reynolds 2001). Nevertheless, field observations in the Galician Rías show that different species of Dinophysis observed during different stages of their population growth and under distinct environmental conditions can exhibit a wide range of values in their intrinsic division rates, between practically zero (Pizarro et al. 2008) and as high as 1 division per day $\left(\mu=0.69 \mathrm{~d}^{-1}\right)$ (see Table 1). Therefore, toxin-producing Dinophysis spp. can divide as quickly as many other mediumsized dinoflagellates (e.g. Alexandrium spp.). Obviously, these observations depend on the chance of sampling the populations at the right time in their seasonal cycle, and at the right depth where they aggregate. Recently, extremely high division rates $\left(\mu=0.95 \mathrm{~d}^{-1}\right)$ have been obtained in laboratory cultures of $D$. acuminata fed with Myrionecta rubra and under continuous illumination (Park et al. 2006). Although growth rates in culture usually include losses due to natural death, these 
results suggest that, under optimal conditions of prey availability and light, $D$. acuminata may become a fastgrowth species with $>1$ doubling per day.

Values of $\mu$ obtained for Dinophysis acuminata during the June cycle, both from integrated samples and from the cell maxima, were of similar magnitude (Table 2). If all possible sources of error (sampling, cell counts, etc.) are considered (Chang \& Carpenter 1990), it can be said that $D$. acuminata was dividing at the same rate throughout the whole water column. Therefore, the high densities of $D$. acuminata observed at 5 to $10 \mathrm{~m}$ by the end of the diel cycle were not caused

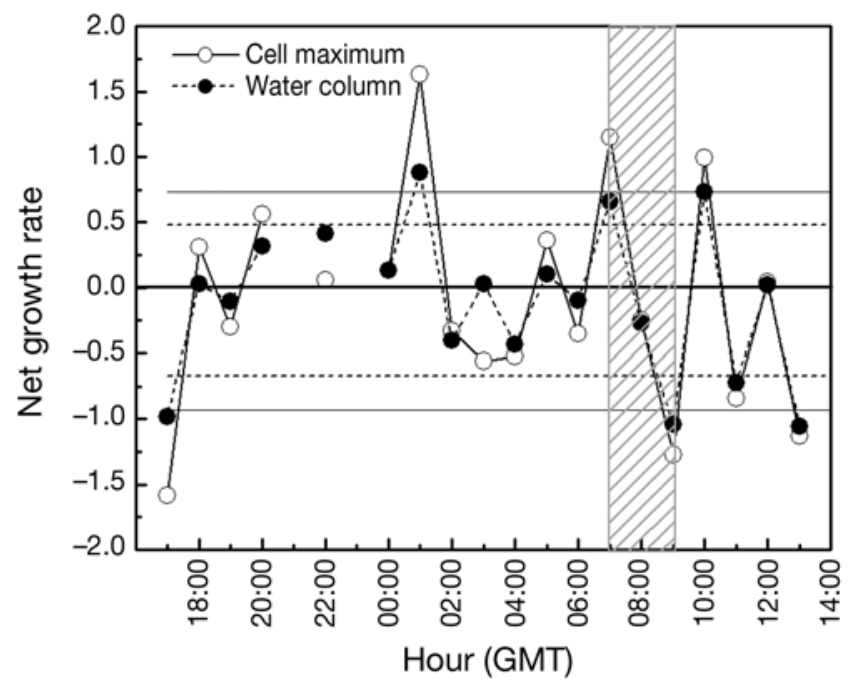

Fig. 6. Dinophysis acuminata. Hourly estimates of net growth rates of the $D$. acuminata population from 1 to 2 June 1994 at Ría de Pontevedra. The shaded area indicates when division was considered. Horizontal lines represent the mean \pm SD for both model results (net growth-rate estimates) of $P_{\max }$ (solid lines) and integrated water samples (dashed lines)

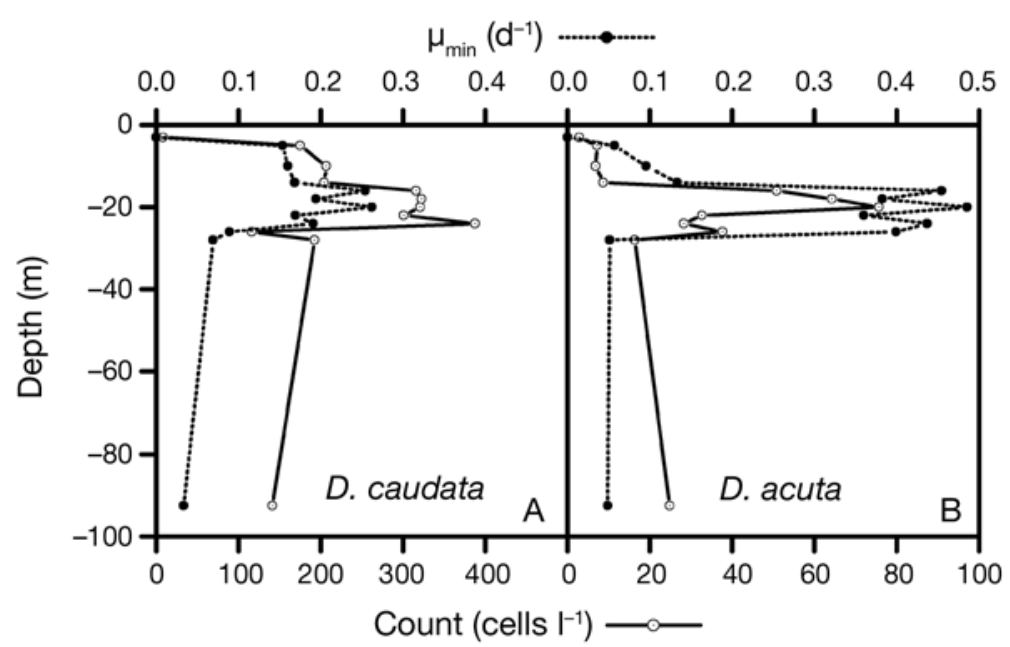

Fig. 7. Dinophysis caudata and D. acuta. Vertical profiles of $\mu_{z}$ estimates (dashed lines) and cell counts (solid lines) for (A) D. caudata and (B) D. acuta on 21 August 2003 at Ría de Vigo (Stn V5) by higher division rates in this depth-interval and must have been caused by advection and vertical migration of Dinophysis cells swimming upwards during the day.

During the October cycle, the estimates of $\mu_{\min }$ and $\mu$ for Dinophysis caudata at the cell maxima were double those obtained from integrated samples (Table 2). Therefore, the accumulation of $D$. caudata within the pycnocline on 27 to 28 October may have been a result of actively dividing cells that aggregated around the density discontinuity. The selection and accumulation of harmful dinoflagellates under downwelling conditions and the advection of coastal populations to the Rías have been well documented for the study area (Fraga et al. 1988, Escalera et al. 2006). In the present study, evidence is given to support the view that increased cell numbers of Dinophysis spp. in the Rías may result from a combination of advection, usually described as the most important factor in dinoflagellate accumulation during downwelling conditions, and enhanced division rates within the cell maxima. Since $\mu$ estimates at $P_{\max }$ were double than those from the integrated water column, integrated water column estimates of $\mu$ from vertical net hauls in this scenario did not provide a realistic measurement of the population growth. Dinophysis spp. often exhibit sharp heterogeneities in their vertical distribution (VeloSuárez et al. 2008); therefore, estimates of $\mu$ from vertical net hauls may conceal much higher division rates occurring in the Dinophysis maximum layer.

In the present study, a deterministic model was applied to a population of Dinophysis acuminata. Positive values of gain and loss rates from 20:00 to 01:00 h, when division did not occur, showed an increment of import factors for both $P_{\max }$ and the integrated water column. Import factors such as advection and vertical migration may have caused the observed increment in D. acuminata numbers from 18:00 to $01: 00 \mathrm{~h}$. Since horizontal advection by wind or tides would affect rate estimates from both sampling methods, differences between integrated samples and $P_{\max } \mu$-estimates could be associated with changes in import or export rates due to swimming behaviour or vertical advection. Significant differences between rates at the $P_{\max }$ and those from integrated samples were found in some time intervals, i.e. from 02:00 to $04.00 \mathrm{~h}$, when the $D$. acuminata maximum moved from 10 to $5 \mathrm{~m}$ and remained at that depth during the rest of the study (Fig. 3B). The estimated rates and the depth of the $P_{\max }$ did not show any further significant differences after 04:00 h (Fig. 3B).

Another peak in net rate occurred during cell division at 07:00 h. Although both $\mu_{\text {int }}$ 
and $\mu_{P_{\max }}$ were included in the model, the estimated rates were above $0.5 \mathrm{~h}^{-1}$, which means that advective gains were higher than losses. This moment coincided with high tide so that, in this case, tidal forcing may have added to active division to increase Dinophysis acuminata concentrations.

Maximum concentrations of Dinophysis spp. have often been related to density gradients, but it is difficult to determine if increased numbers found in these layers are due to in situ division rate, physical accumulation or a combination of both (Maestrini 1998). Pizarro et al. (2008) showed that even in the case of a decaying population of $D$. acuta, with a division rate of almost zero (Table 1), Dinophysis spp. cells still aggregated in a maximum around the halocline. Based on the results obtained in the present study, it is strongly recommended that division rates should be measured from samples collected at the $P_{\max }$ rather than from vertical hauls. During stratified conditions, estimates of $\mu$ either from haul samples or from samples collected at discrete depths not associated with $P_{\max }$ may give strong underestimates of the potential division rates of the population. Our results also show that the key question - Are the increased numbers of Dinophysis spp. at discrete depths due to biology or to physics? can be answered by obtaining estimates of $\mu$ at different and representative discrete depths.

\section{CONCLUSIONS}

A comparison of division rates estimated from integrated and depth-specific samples of Dinophysis spp. was carried out. The observed differences between $\mu$ estimates at the $P_{\max }$ and from integrated samples were negligible during the June 1994 cycle, but the $D$. acuminata population was actively dividing $(\mu=0.4)$ in the absence of water column stratification. High cell densities in this case were mainly driven by vertical migration and advection. In contrast, the population of D. caudata during the October 1994 cycle provides a good example of numerical increase due to enhanced division in the pycnocline.

Values of $\mu_{z}$ obtained from vertical profiles in 2003 showed the vertical heterogeneity of Dinophysis spp. concentration and division. Division rates at $P_{\max }$ $(20 \mathrm{~m})$ were double in the case of $D$. caudata, and 5 times higher in the case of D. acuta, than rates observed in the layers above and below. $\mu_{\text {int }}$ value of this profile would not have been a realistic measurement of the population growth rate at the time. Vertical heterogeneities in division rate estimates justify the importance of fine-scale sampling to detect layers of actively dividing Dinophysis spp. These layers which may represent hot spots of actively dividing cells, and have a decisive effect on the population dynamics of the target species - can be missed with conventional sampling methods. Although further research is needed, measuring division rates where cells aggregate, i.e. at the cell maxima, provides a more realistic indicator of population growth for Dinophysis spp. dynamics and for the application of predictive models.

Acknowledgements. We thank the crew of RV 'J.M. Navaz' for their help, the Galician Monitoring Programme (INTECMAR) for weekly supply of information on oceanographic and phytoplankton data on the Galician Rías, J. M. Cabanas for supply of upwelling index estimates and I. Ramilo for technical assistance. This research was supported by projects HABIT (EU GOCE-CT-2005-003932) and Dinophysis Galicia (CTM2004-0478-CO3-01) and is a contribution to the GEOHAB Programme-Core Research Project on HABs in Stratified Systems. E.G. was supported by a Ramón y Cajal contract from the Spanish Ministry of Science and Education.

\section{LITERATURE CITED}

Anonymous (1991) Council Directive 91/492/EEC of 15 July 1991 laying down the health conditions for the production and the placing on the market of live bivalve molluscs. Off J Eur Communities L268:1-14

Anonymous (2002) Decisión de la Comisión 2002/225/CE de 15 de marzo de 2002, por la que se establecen normas detalladas para la aplicación de la Directiva 91/492/CEE del Consejo. Off J Eur Communities L75:62-64

Bakun A (1973) Coastal upwelling indices, west coast of North America 1946-17. NOAA Tech Rep NMFS SSRF-671

Carpenter EJ, Chang J (1988) Species-specific phytoplankton growth rates via diel DNA synthesis cycles. I. Concept of the method. Mar Ecol Prog Ser 43:105-111

Chang J, Carpenter EJ (1990) Species-specific phytoplankton growth rates via diel DNA synthesis cycles. IV. Evaluation of the magnitude of error with computer-simulated cell populations. Mar Ecol Prog Ser 65:293-304

Chang J, Carpenter EJ (1991) Species-specific phytoplankton growth rates via diel DNA synthesis cycles. V. Application to natural populations in Long Island Sound. Mar Ecol Prog Ser 78:115-122

Escalera L, Reguera B, Pazos Y, Moroño A, Cabanas JM (2006) Are different species of Dinophysis selected by climatological conditions? Afr J Mar Sci 28:283-288

Fraga S, Anderson DM, Bravo I, Reguera B, Steidinger KA, Yentsch CM (1988) Influence of the upwelling relaxation on dinoflagellates and shellfish toxicity in Ría de Vigo, Spain. Estuar Coast Shelf Sci 27:349-361

Franks PJS (1997) Models of harmful algal blooms. Limnol Oceanogr 42:1273-1282

Garcés E, Masó M (2001) Phytoplankton potential growth rate versus increase in cell numbers: estimation of cell lysis. Mar Ecol Prog Ser 212:297-300

Garcés E, Delgado M, Camp J (1997) Phased cell division in natural population of Dinophysis sacculus and the in situ measurement of potential growth rate. J Plankton Res 19: 2067-2077

> Gisselson LÅ, Granéli E, Carlsson P (1999) Using cell cycle analysis to estimate in situ growth rate of the dinoflagellate Dinophysis acuminata: drawbacks of the DNA quantification method. Mar Ecol Prog Ser 184:55-62 
Gisselson LA, Carlsson P, Granéli E, Pallon J (2002). Dinophysis blooms in the deep euphotic zone of the Baltic Sea: Do they grow in the dark? Harmful Algae 1:401-418

Lovegrove T (1960) An improved form of sedimentation apparatus for use with an inverted microscope. ICES J Mar Sci 25:279-284

Maestrini SY (1998) Bloom dynamics and ecophysiology of Dinophysis spp. In: Anderson DM, Cembella AD, Hallegraeff GM (eds) Physiological ecology of harmful algal blooms. NATO ASI Ser Ser G Ecol Sci 41:243-266

McDuff RE, Chisholm SW (1982) The calculation of in situ growth rates of phytoplankton populations from fractions of cells undergoing mitosis: a clarification. Limnol Oceanogr 27:783-788

Park MG, Kim S, Kim HS, Myung G, Kang YG, Yih W (2006) First successful culture of the marine dinoflagellate Dinophysis acuminata. Aquat Microb Ecol 45:101-106

Pizarro G, Escalera L, González-Gil S, Franco JM, Reguera B (2008) Growth, behaviour and cell toxin quota of Dinophysis acuta during a daily cycle. Mar Ecol Prog Ser 353: 89-105

Reguera B, Pizarro G (2008) Planktonic dinoflagellates which produce polyether toxins of the old 'DSP complex'. In: Botana L (ed) Seafood and freshwater toxins: pharmaco-

Editorial responsibility: Katherine Richardson,

Copenhagen, Denmark logy, physiology and detection, 2nd edn. Taylor \& Francis, London, p 257-284

Reguera B, Garcés E, Pazos Y, Bravo I, Ramilo I, Gonzáles-Gil S (2003) Cell cycle patterns and estimates of in situ division rates of dinoflagellates of the genus Dinophysis by a postmitotic index. Mar Ecol Prog Ser 249:117-131

Smayda T, Reynolds CS (2001) Community assemblage in marine phytoplankton: application of recent models to harmful algae blooms. J Plankton Res 23:447-461

Stolte W, Garcés E (2006) Ecological aspects of harmful algal in situ population growth rates. In: Granéli E, Turner JT (eds) Ecology of harmful algae. Springer-Verlag, Berlin, p 139-152

Utermöhl H (1931) Neue wege in der quantitaven Erfassung des Planktons (mit besonderer Berücksichtigung des Ultraplanktons). Verh Int Ver Theor Angew Limnol 5: 567-596

Velo-Suárez L, González-Gil S, Gentien P, Lunven M, Bechemin C, Fernand L, Raine R (2008) Thin layers of Pseudo-nitzschia spp. and the fate of Dinophysis acuminata during an upwelling-downwelling cycle in a Galician Ría. Limnol Oceanogr 53:1816-1834

Weiler CS, Chisholm SW (1976) Phased cell division in natural populations of marine dinoflagellates from shipboard cultures. J Exp Mar Biol Ecol 25:239-247

Submitted: April 8, 2008; Accepted: March 18, 2009 Proofs received from author(s): May 27, 2009 